\title{
ON PUBLIC DANGER AS A FACTOR OF CRIMINALIZATION (DECRIMINALIZATION) OF VIOLATION OF THE ESTABLISHED RULES OF CIRCULATION OF NARCOTIC DRUGS
}

\author{
Viktoriia Lisniak ${ }^{1}$ \\ ${ }^{1}$ Judge, Krynychky District Court of Dnipropetrovsk Oblast, Krynychky, Dnipropetrovsk Oblast, Ukraine, e- \\ mail:inbox@kn.dp.court.gov.ua
}

Abstract. The article examines the problem of social conditionality of criminal legal prohibition. The phenomenon of public danger is analyzed as a factor of criminalization (decriminalization) of violation of the established rules of circulation of narcotic drugs, psychotropic substances, their analogues or precursors intended for the production or manufacture of these drugs or substances. The aim of the article: to establish the existence or lack of social conditionality of criminal liability for the violation of established rules of circulation of narcotic drugs, psychotropic substances, their analogues or precursors through the perception of the phenomenon of public danger as a factor of criminalization (decriminalization) of certain acts. The research methodology: historical and legal, systemic, dogmatic, hermeneutic ones. The debatable provisions of this issue are considered, the author's critical considerations are stated. The scientific position of Ukrainian criminologists is supported, according to which the feature "public danger" of an act should not be applied in the legislative definition of a crime. However, this does not mean that the legislator should be deprived of the need to take into account the public danger (or lack thereof) of certain actions in the process of resolving the issue of their criminalization (decriminalization). The expediency of editorial adjustment of Part 1 of Art. 320 of the Criminal Code of Ukraine has been substantiated. The criminal consequence, which is planned to express significant harm, should be the shortage of narcotic drugs, psychotropic substances, their analogues or precursors on a large scale.

Keywords: public danger, crime, social conditionality, criminalization (decriminalization) of an act, factors of criminalization, circulation of narcotic drugs, narcotic drugs, psychotropic substances and their analogues, precursors.

JEL Classification: K10, K14, K39

Formulas: 0; fig.: 0; tabl.: 0; bibl.: 18 .

Introduction. The problem of social conditionality of criminal legal prohibition is closely related to such a method of criminal legal policy as criminalization of acts. Having established the existence of grounds for acknowledging a certain act as criminal (or the lack of such grounds), the legislator quite reasonably makes a relevant decision. This indicates the relevance of the study of the declared topic. In the theory of criminal law, these problems are paid with considerable attention, but it cannot be considered sufficient. Creative efforts are required both at the level of the general doctrine of the social conditionality of criminal liability, and at the level of perception of the analyzed issues in relation to certain individual corpus delicti.

Literature Review. The study is based on domestic and foreign doctrine. Various criminal law sources have been applied - the Criminal Code of Ukraine, monographs, theses, textbooks, encyclopaedic publications, articles, judgments of the Supreme Court of Ukraine.

Aims. The aim of the article is to establish the existence or lack of social conditionality of criminal liability for the violation of established rules of circulation of narcotic drugs, psychotropic substances, their analogues or precursors through the 
perception of the phenomenon of public danger as a factor of criminalization (decriminalization) of certain acts.

Methods. The study has applied traditional methodological tools, in particular such methods as historical and legal, systemic, dogmatic, hermeneutic ones.

Results. In the educational literature on criminal law, the term "criminalization" means the definition of certain acts as crimes with the provision of the elements of the crime and the establishment of punishment for its commission in a relevant article of the Special Part of the criminal law [1, p. 113].

The author of the above definition refers to the concept of criminalization formulated by Sviatoslav Tararukhin in Volume 3 of the Juridical Encyclopaedia of 2001 [2, p. 392].

Another definition of criminalization has been proposed by Oleksandr Dudorov in the Big Ukrainian Legal Encyclopaedia: "criminalization is a term used in criminal law to denote the process and result of classifying acts as crimes. Criminalization is the detection of socially dangerous manifestations of human behaviour, acknowledgement by the state of the possibility and necessity of applying criminal liability measures against them and enshrining features of socially dangerous acts recognized as crimes in criminal law" [3, p. 459].

Thus, the above indicates more or less stable doctrinal comprehension of the concept of criminalization. However, this is not the case with other aspects of criminalization theory. Thus, Oleksandr Dudorov has rightly remarked: "Herewith, the issue of the concept of grounds, principles, conditions, reasons for criminalization, their number, classification, content and correlation are referred to debatable ones". Nevertheless, this scholar expressed the opinion that the relevant discussions had not so much substantive as terminological nature, in fact, they were not about the essence of the criminalization rules, but about their systematization (grouping) and the general name of such requirements [3, p. 461].

In the thesis of Daria Balobanova the opinion about necessity of consideration of two groups of the factors influencing criminalization is made: 1) the grounds for the criminal legal prohibition which serve as objective preconditions for its establishment; 2) the principles of criminalization related to the legislative technique [4, p. 177]. We emphasize that in the future we will first consider the first group of factors, or the grounds for the criminal legal prohibition.

The problematics of factors (reasons, grounds, etc.) of criminalization has been studied for some time by the theory of criminal law, resulting in several proposed systems of accounting such factors. According to Kazakh researcher Bakhtybai Zhunusov, in total there are about 20 factors of criminalization [5, p. 40].

The analysis of criminalization factor systems proposed in science goes beyond the subject of our research and needs separate study; we deliberately limit the depth of research on this issue and try to choose a system that effectively performs the tasks set before it and is recognized by most scholars. In our opinion, one of these is the system of grounds (more precisely, factors) of criminalization proposed by Alexander Korobeev. This scholar identifies three groups of factors of criminalization 
(decriminalization): legal-criminological, socio-economic, socio-psychological [6, p. 69].

The first group (legal-criminological) is formed by: a) the degree of public danger of the act; b) the relative prevalence of acts and their typicality; c) the dynamics of actions, taking into account the causes and conditions that give rise to them; d) the possibility of influencing these acts by criminal legal means in the absence of the possibility of effective struggle by less repressive means; e) the possibilities of the criminal justice system. The second group (socio-economic) is consists of: a) material or moral damage caused by the act; b) the absence of possible side effects of criminalization of the act; c) the availability of material resources for the implementation of the ban. The third group (socio-psychological) includes: a) a certain level of social legal awareness and psychology; b) historical traditions [6, p. 69]. The fact that O. Pashchenko, a domestic researcher of the social conditionality of the law on criminal liability, largely supports the views of Alexander Korobeev, may be indicative for the perception of Alexander Korobeev's approach [7, p. 127, 130].

Let us analyze the "degree of public danger of the act" - a factor of criminalization, belonging to the first group. This factor is not accidentally in the first place, because it is given a leading role in the theory of criminalization. However, the key concept that serves as the basis for this factor is debatable in the theory of criminal law. It is about the meaning of the concept of "public danger".

First of all, we note that in the science of criminal law of the Soviet period, the concept of "public danger" was perceived as fundamental, one that permeates the entire system of criminal law. Some discussions revolved around the meaning of the public danger concept, the nature and degree of public danger, etc., but the need for the existence of the "public danger" category as a constituent element of offence was not questioned. The situation has changed radically in the contemporary criminal law science of Ukraine. Domestic scholars have recently begun to pay attention to the content of public danger and its criminal legal significance.

Denys Azarov devoted a number of scientific works to the problem of public danger. Thus, in the article "Social danger of crime and analogy of criminal law (retrospective view in the XIX - XX centuries)" the scholar proves the existence of a close connection between the existence of the substantive definition of the crime, which was based on the category of public danger, in the Criminal Code of the Ukrainian Socialist Soviet Republic (USSR) of 1922 and in its revised edition of 1927, and the application of criminal law by analogy. In addition, a hypothesis is expressed about the need to exclude a feature of public danger from the current legislative definition of "crime" and the feasibility of restructuring the existing system of differentiation and individualization of criminal liability using clear formalized criteria [8, p. 139-145].

At the same time, Denys Azarov makes the following warning: "The above raises serious doubts concerning the rationality of transforming public danger into a cornerstone of criminal law, on the subjective assessment of which almost any decision in the criminal law sphere now depends. However, the substantiation of these doubts requires arguments that cannot be included into this publication (in 
particular, the averment of the lack of unambiguous perception of the public danger category in science and in practice, the establishment of this category importance for the differentiation and individualization of criminal liability, the publication of the results of comparative legal research). Therefore, presently, I have the right to speak only about the hypothetical expediency of excluding the feature of public danger from the legal definition of the term "crime". Public danger as the ability of an act to cause or create a threat of harm is certainly the main substantive quality of a crime, regardless of whether such a quality is enshrined in law. However, in my opinion, this law should be based on much more formalized categories, which should be founded, particularly, on the results of scientific research on the public danger of certain types of crimes" [8, p. 144]. As can be seen from the above, at that time Denys Azarov did not deny that public danger was the main substantive feature of the crime; the scholar only expressed doubts regarding the need to enshrine this category in the legislative definition of the concept of crime.

In his further scientific investigations, he was finally convinced of his rightness $[9$, p. 3-18] and his substantiated research results undoubtedly influenced the attitude of members of the working group on the development of criminal law within the Commission for Legal Reform, established by the Decree of the President of Ukraine of August 7, 2019, to this problem. In their draft General Part of the Criminal Code, the concept of a crime is defined without the use of the feature "public danger" [10]. We share this approach. However, this does not mean that the legislator should be deprived of the need to take into account the public danger (or lack thereof) of certain actions in the process of resolving the issue of their criminalization (decriminalization).

Less balanced and more categorical approach is followed by Volodymyr Shablystyi, according to whom "public danger as a key category of criminal law is an artificially created rudiment of the Soviet legal heritage, because in the early twentieth century the phrases "socially dangerous" and "criminal" were synonymous; in fact, such a situation ruled out illegality as a feature of a crime and became the basis for the applying the analogy of criminal law. Public danger should not be acknowledged as a determining factor in distinguishing crimes from other offenses, because in the current Criminal Code of Ukraine there are crimes that are not clearly dangerous (for example, Part 1 of Article 185 of the Criminal Code of Ukraine)" [11, p. 11]. Regarding the position of this scholar, we should note the following. The history of the development of scientific schools of criminal law proves that the concept of an action's danger to society arose in the depths of the sociological school of criminal law (XIX century), so there is no sufficient basis to consider the category of "public danger" as a product of Soviet criminal legal science.

Let us try to find out what is the social danger of violating the established rules of the circulation of narcotic drugs, psychotropic substances, their analogues or precursors, what is its degree and whether such an act is really socially dangerous.

First, let us resort to the design of the relevant article (Article 320 of the Criminal Code of Ukraine). The article provides two parts of such content: 
"1. Violation of established rules on planting or cultivation of opium poppy or cannabis, and also violation of rules on production, making, storage, inventorying, dispensation, distribution, commercial sale, transportation, sending or use of narcotic drugs, psychotropic substances, their analogues or precursors designated for production or making of such drugs or substances, -

shall be punishable by a fine up to 70 tax-free minimum incomes, or detention for a term up to six months, or restraint of liberty for a term up to four years, or imprisonment for a term up to three years, with the deprivation of the right to occupy certain positions or engage in certain activities for a term up to three years.

2. The same actions, if repeated, or where they resulted in shortage of narcotic drugs, psychotropic substances, their analogues or precursors in gross amounts, or in stealing, appropriation, extortion of narcotic drugs, psychotropic substances, their analogues or precursors or their abstraction by fraud or abuse of office, -

shall be punishable by a fine of 70 to 120 tax-free minimum incomes, or detention for a term of three to six months, or imprisonment for a term of three to five years, with the deprivation of the right to occupy certain positions or engage in certain activities for a term up to three years".

It is important to emphasize that Part 1 of Art. 320 of the Criminal Code of Ukraine contains a corpus delicti, which by the design of the objective side belongs to the formal ones. The crime will be considered completed from the moment of committing any of the acts provided by the disposition of the criminal legal norm. In our opinion, such a design of corpus delicti creates a number of risks for citizens, who legally participate in circulation of narcotic drugs. Any, even insignificant, deviation from the rules may already constitute a crime under Part 1 of Art. 320 of the Criminal Code of Ukraine. Understanding this, some authors (including Yurii Baulin) while providing their scientific and practical commentaries on the relevant article tried to add legal certainty to these rules through the following provisions: "Liability for the crime under Part 1 of Art. 320 of the Criminal Code is incurred, only when the violation of these rules is fundamental, i.e. creates a real danger to human health or the loss of control over narcotic drugs, psychotropic substances, their analogues or precursors. Minor violation of these rules in accordance with Part 2 of Art. 11 of the Criminal Code is not recognized as a crime" [12, p. 665-666]. However, the evaluative nature of the concept of "fundamental violation of the rules" again deprives the possibility of a clear division between criminal and non-criminal forms of behaviour. In addition, textually Part 1 of Art. 320 of the Criminal Code of Ukraine does not contain instructions on the concept of "fundamental" violation.

The concept of "substantial harm" belongs to the pervasive criminal legal categories, but it has not often been the subject of scientific study. In Ukraine, only in 2017, the first thesis was devoted to the study of the concept of "substantial harm" [13]. The author of this work R. Lemekha drew an inference about the content of the concept of substantial harm, resulting in his proposal of the following obligatory features of this concept: "such harm is a direct actual damage; may be pecuniary, as well as expressed in the negative consequences of physical, moral or other nonmonetary nature; the harm is substantial under a certain amount, which is not the 
same regarding individual corpus delicti; indicates such changes in the object, which confirm the public danger of encroachment, substantiate criminalization and the lack of insignificance" [14, p. 11]. In our opinion, in general, the approach of R. Lemekha can be accepted. The features of substantial harm identified by this author are supported by patterns found in previous studies of the problem, carried out in Soviet times. Emphases on the consequences, changes in the object, the significance for criminalization are important.

At the same time, we believe that the doctrine of criminal law has proposed simpler, but no less effective lists of factors that reveal the meaning of the concept of "substantial harm". Thus, while considering public danger as a criterion for criminalization, Rashid Sabitov notes that the act must be criminalized, when it causes or threatens to cause substantial harm to the object. The scholar believes that the harm can be regarded as substantial upon availability of certain factors: the value of social relations, to which it is caused, the quantitative characteristics of the harm, the socio-political situation in which the act is committed [15, p. 25]. We agree with Mr. Sabitov's approach and consider it necessary to extend it to the analysis of factors that collectively form the concept of substantial harm, especially since substantial harm is an integral attribute of the degree of public danger of the act. Thus, the components that form the content of the substantiality of harm concept are: 1) the value of social relations, to which this harm is inflicted; 2) quantitative characteristics of the harm; 3) the socio-political situation in which the act is committed. Let us consider them.

The danger of the spreading drug addiction for public relations is analyzed in detail in the works of Anatolii Muzyka. "Drug addiction as a disease and drug trafficking are among the global problems of today. These phenomena are characterized by a high degree of public danger, due to severe consequences not only for the health of an individual, but also for public health (health of the population), the economy, for each individual family and society as a whole", - the scholar emphasizes [16, p. 8]. It seems that the value of the objects of criminal legal protection mentioned in the above quote is beyond any doubt.

The socio-political situation in which the act is committed is characterized as drug addiction epidemic [16, c. 9].

From December 25, 1979 till February 15, 1989, the Soviet invasion of Afghanistan continued. This period is characterized by a significant increase in "narcotic" criminality and the spread of drug addiction in the USSR. Last but not least, this happened as a result of the involvement of our military servicemen in drug use, due to the smuggling of the latter from Afghanistan to Ukraine and other republics of the Union.

In addition, if we talk about the need to maintain criminal liability for violating the established rules of narcotic drugs circulation, since February 2014, our country has been attacked by the Russian Federation, which resulted in the occupation of 44 thousand square kilometres or $7 \%$ of the territory of Ukraine. We are in fact at war with the north-eastern "neighbour"; this fact inevitably affects the sociopsychological state of a significant number of people. Under such unstable 
conditions, the mental health becomes vulnerable to the influence of the media, various totalitarian sects, pseudo-religious organizations, alcohol and psychoactive substance abuse. In the described socio-political situation, the state must resort to systematic measures to counteract the spread of non-medical drug use and introduce criminal legal norms of double prevention.

In the doctrine of criminal law since the mid-60's of the XX century attention is drawn to a special group of criminal legal norms called "double prevention norms". Thus, Anatolii Zelinskyi noted in his thesis that "there is a typical species relationship between different types of crimes. It is manifested in the fact that some crimes create conditions for others, often more serious. We can distinguish a relatively small group of crimes, the public danger of which is characterized by the creation of typical conditions for criminality. Fighting against them has an important preventive value" [17, p. 9-14]. Another researcher of the preventive function of criminal legal norms E. Sarkisova has rightly noted that these norms perform their general preventive function by means of imposing sanctions for actions that may result in even more serious crimes or contribute to the commission of offenses. These, according to the scholar, include: threat of murder, drunk driving, careless storage of firearms, involvement of minors in criminal activities, malicious violation of the rules of administrative supervision and other norms [18, p. 16].

In our opinion, there is every reason to consider the provisions of Art. 320 of the Criminal Code of Ukraine as double prevention norms. The social danger of violating the established rules of the circulation of narcotic drugs, psychotropic substances, their analogues or precursors is caused by the fact that such acts may serve as determinants of other crimes in the field of circulation of narcotic drugs. This point can be confirmed not only by empirical research or logical methods, but also by the position of the legislator, who had noted directly in Part 2 of Art. 320 of the Criminal Code that the actions provided in Part 1 of this article may result in the theft, misappropriation, extortion of narcotic drugs, psychotropic substances, their analogues or precursors or their acquisition by fraud or abuse of office by an official. In addition, the loss of control over narcotic drugs can result in their sale to other persons (Article 307 of the Criminal Code of Ukraine), to their illegal injection in the body of another person against his/her will (Article 314 of the Criminal Code of Ukraine), and so on.

Thus, the socio-political situation, in which the violation of established rules of circulation of narcotic drugs, psychotropic substances, their analogues or precursors is committed, is a condition for acknowledging the substantial nature of the harm caused (or which may be caused) as a result of these acts.

The last factor of the substantiality of harm is its quantitative characteristics. First of all, we note: due to the fact that the quantitative characteristics of the harm from the acts provided in Part 1 of Art. 320 of the Criminal Code of Ukraine has not yet been determined by the legislator, we are obliged to draw attention to this and to correct this shortcoming on a theoretical level. We believe that to characterize the substantiality of harm in this case, it is difficult to take into account only the value of social relations and socio-political situation. 
Study of peculiarities of legislative technique of designing Parts 1 and 2 of Art. 320 of the Criminal Code of Ukraine raises the opinion on a significant gap in the degree of public danger between the acts provided in Parts 1 and 2 of this article. The first part of the analyzed article does not envisage the ensuing of consequences in the form of shortages of narcotic drugs, psychotropic substances, their analogues or precursors, while the second part envisages such a shortage in gross amounts.

Conclusion. As a result of our research, we found that public danger is inherent in violation of the established rules of circulation of narcotic drugs, psychotropic substances, their analogues or precursors intended for the production or manufacture of these drugs or substances (Article 320 of the Criminal Code of Ukraine). This indicates the existence of social conditionality in the criminalization of such acts. At the same time, Part 1 of this article needs to be improved, as it contains the corpus delicti, which by the construction of the objective element belongs to the formal ones. The crime will be considered completed from the moment of committing any of the acts provided by the disposition of the criminal legal norm. We believe that this design of the corpus delicti creates a number of risks for citizens who legally participate in circulation of narcotic drugs. Any, even insignificant, deviation from the rules may already constitute the corpus delicti under Part 1 of Art. 320 of the Criminal Code of Ukraine.

In our opinion, the corpus delicti currently contained in Part 1 of Art. 320 of the Criminal Code of Ukraine and does not provide the consequences of violating certain norms, should be transferred to the category of misdemeanour offense. In return, Part 1 of Art. 320 of the Criminal Code of Ukraine needs to be stated in a new edition, as the logic of the design of article and the legislative technique require to transform this corpus delicti from formal to substantive. The criminal consequence, which is planned to express substantial harm, should be represented by the shortage of narcotic drugs, psychotropic substances, their analogues or precursors on a large scale.

\section{References:}

1. Navrotskyi, V. (2013), Ukrainian criminal law. General part, Yurinkom Inter, Kyiv, 712 p.

2. Shemshuchenko, Yu. and other (2001), Juridical Encyclopaedia: in 6 v., Ukraine Encycl., Kyiv, 392 p.

3. Tatsii, V. Borysov, V. and other (2017), "Big Ukrainian Legal Encyclopaedia: in 20 v. V. 17", Criminal law, National Academy Legal Sciences of Ukraine; V. M. Koretsky Institute of State and Law of the National Academy of Sciences of Ukraine; Yaroslav Mudryi National Law University, Pravo, Kharkiv, 459 p.

4. Balobanova, D. (2007), “Theory of criminalization”, PhD thesis, Law, Odesa, 208 p.

5. Zhunusov, B. (1994), Problems of criminal policy (criminal legal and criminal executive), Almaty, $46 \mathrm{p}$.

6. Korobeev, A. (1987), Soviet criminal legal policy: problems of criminalization and penalization,

Publishing office of the Far Eastern University, Vladivostok, 269 p.

7. Pashchenko, O. (2018), Social conditionality of the law on criminal liability, Yurait, Kharkiv, 446 p.

8. Azarov, D. (2015), "Social danger of crime and analogy of criminal law (retrospective view in the XIX XX centuries)", Scientific notes of the National University of "Kyiv-Mohyla Academy". Legal sciences, volume 168 , pp. 139-145.

9. Azarov, D. (2019), "Understanding the public danger of crime (according to the results of a sociological experiment)", Scientific notes of the National University of "Kyiv-Mohyla Academy", Legal sciences, volume 3. P. $3-18$.

10. The Verkhovna Rada of Ukraine (2001), The Law of Ukraine "Criminal Code of Ukraine". URL: https://newcriminalcode.org.ua/upload/media/2020/09/16/1-kontrolnyj-proekt-kk-15-09-2020.pdf.

11. Shablystyi, V. (2016), "Theoretical and applied principles of criminal legal ensuring human security in Ukraine", abstract of thesis to obtain the scientific degree of Doctor of Juridical Sciences, Kharkiv, 36 p. 
12. Baulin, Yu. Borysov, B. Tiutiuhin, V. and others (2013), Criminal Code of Ukraine. Scientific and practical commentary: in 2 v., Pravo, Kharkiv, $1040 \mathrm{p}$.

13. Lemekha, R. (2017), "The concept of substantial harm under the criminal law of Ukraine", PhD thesis, Law, Lviv, 196 p.

14. Lemekha, R. (2017), "The concept of substantial harm under the criminal law of Ukraine", abstract of PhD dissertation, Law, Lviv, 18 p.

15. Sabitov, R. (1980), Public danger as a criterion for criminalization. Actual problems of criminalization and decriminalization of socially dangerous acts: collection of research papers, Research and publishing department of Omsk Higher School of Police of the MIA USSR, Omsk, pp. 23-36.

16. Muzyka, A. (1998), Liability for crimes in the field of circulation of narcotic drugs, Lohos, Kyiv, $324 \mathrm{p}$. 17. Zelinskii, A. (1966), "Significance of criminal law norms for the prevention of crime", abstract of PhD, dissertation, Law, Moscow, 19 p.

18. Sarkisova, E. (1975), Criminal legal means of crime prevention, Science and technology, Minsk, 192 p.

Received: August 10, 2020

Approved: September 15, 2020 